\title{
The beauty of "Some Rights Reserved" Introducing Creative Commons to librarians, faculty, and students
}

$\mathbf{T}$ hese are dif cult times when it comes to copyright on campus. Big music companies are suing fans, publishers are suing librarians, and the principle of fair use is under siege everywhere. Litigation-happy content holders have fostered a climate of fear in which every student is a music pirate and every professor a book thief. While I don t doubt that there is some copyright infringement happening on university campuses, the bigger problem by far is the chilling effect of all these lawsuits and copyright awareness campaigns.

Scholars and students are afraid to do the one thing that copyright law has intended from the beginning: Promote the Progress of Science and the Useful Arts ${ }^{1}$ by creating new works and building on the works of those who came before. Every academic librarian knows at least one sad story about a professor who couldn t include necessary illustrations in her book because her publisher was worried about a copyright lawsuit, or a digitization project that couldn t get approved because the copyright status of the materials was uncertain.

Additional problems result from major changes to copyright law over the last 40 years. Until recently, creators had to register their copyrights to receive protection and mark their works with a properly formatted copyright notice or the work entered automatically into the public domain, where anybody was free to reuse it however they wished.

That all changed in 1978, when the United States dropped the registration requirement; since then, copyright automatically occurs the moment a work is xed in a tangible medium of expression. Now, every new work is copyrighted lecture notes, e-mails, snapshots, doodles, presentation slides. And where once copyright lasted for 14 years, with the option to renew for another 14, now copyright lasts for the lifetime of the author, plus an additional 70 years after the author s death, for an average duration of more than a century. That $s$ a very long time, and it leaves thousands of works orphaned: under copyright but without a locatable copyright holder. Between the fear and the orphans, life is hard for an ordinary academic who just wants some pictures to liven up her classroom presentations, or the student who would like to add a soundtrack to his nal project.

\section{Enter Creative Commons}

Creative Commons is a nonpro t organization that created a set of simple, easy-to-understand copyright licenses. These licenses do two things: They allow creators to share their work easily, and they allow everyone to nd work that is free to use without permission. The value of those two things is enormous. Before Creative Commons licenses, there was no easy way a creator could say, Hey world! Go ahead and use my photographs, as long as you give me attribution.

Similarly, there was no place for members of the public to go to nd new works that

Molly Kleinman is copyright specialist at the University of Michigan Library, e-mail: makleinm@umich.edu

๑) 2008 Molly Kleinman 
they were free to reuse and remix without paying fees. Creative Commons changed all that. As it says on its Web site, Creative Commons de nes the spectrum of possibilities between full copyright all rights reserved and the public domain no rights reserved. Our licenses help you keep your copyright while inviting certain uses of your work a some rights reserved copyright. ${ }^{2}$

The licenses come in three languages: Human Readable, which is a very brief and easy-to-understand summary of what is permitted and under what conditions; Lawyer Readable, which is a legally binding threepage deed; and Machine Readable, which is the metadata, a little snippet of code that makes it possible for search engines like Google to search by Creative Commons license, and return only those works that are free to reuse.

There are six major Creative Commons licenses that all include different combinations of four basic requirements:

(i) Attribution: You let others copy, distribute, display, and perform your copyrighted work and derivative works based upon it but only if they give you credit the way you request. This element is a part of all six licenses.

\$) Non-Commercial: You let others copy, distribute, display, and perform your work

and derivative works based upon it but for noncommercial purposes only.

$\ominus$ No Derivatives: You let others copy, distribute, display, and perform only exact copies of your work, not derivative works based upon it.

(2) Share Alike: You allow others to distribute derivative works only under a license identical to the license that governs your work.

Founded by a group of intellectual property and technology experts in 2001, Creative Commons has emerged as a major player in the growing movement to provide an alternative to All Rights Reserved. Their goal is to build a layer of reasonable, exible copyright in the face of increasingly restrictive default rules. ${ }^{3}$ They appear to be succeeding. As of this writing, Creative Commons licenses are available in 44 countries, with 9 more on the way. There are more than 60 million photographs available under Creative Commons licenses on the popular photo sharing Web site Flickr ( ickr.com); nearly 10,000 sound clips, samples, and remixes on the music site ccMixter (ccmixter. org); and materials from 1,800 undergraduate and graduate level MIT courses in the MIT OpenCourseWare program (ocw.mit.edu).

\section{Benefits of Creative Commons in academic settings}

The most immediate bene $t$ of Creative Commons licenses to academia is the wealth of new works that are available for use without permissions or fees. Instructors, librarians, and students no longer have to rely on the public domain for materials that they can repurpose without risk of copyright infringement. In the time it takes to do a Google search, members of our community can nd Creative Commons-licensed photographs, illustrations, music, video, and educational resources, and they're all free.

Creative Commons answers one of the most common copyright questions librarians get: Is it okay for me to use this photograph/article/ gure/etc. in my classroom/ article/Web site/etc.? If the photograph/article/ gure is Creative Commons-licensed, the answer is always Yes. At the University of Michigan Library, we decided we wanted to get the word out to our faculty and librarians to encourage them to take advantage of the incredible resources available through Creative Commons, and to contribute to those resources by licensing their own work.

\section{Online extra}

Visit the November 2008 issue of CERL News online at www.acrl.org/c\&rlnews for a podcast interview with article author Molly Kleinman. 


\section{Teaching Creative Commons}

It may be easy to see the appeal of 60 million free photos, or 10,000 free songs, but it can be hard to understand exactly what Creative Commons is without some context. At the University of Michigan Library, we have included Creative Commons in a larger copyright outreach campaign that began in May 2007. The campaign targets university faculty, researchers, students, staff and librarians, and aims to raise community members awareness of their rights as authors and creators, improve their understanding of fair use, and promote a balanced approach to copyright. It has involved the redesign of the university s copyright Web site, outreach to academic departments through their subject specialists, and a series of copyright workshops offered in the library.

We offered the rst Creative Commons workshops in May 2007 to all members of the university community, and followed up with a similar set of workshops designed as staff development training for librarians and library workers in January 2008.

The basic outline of the workshops is as follows:

1) introduction to Creative Commons,

2) a few key facts about copyright,

3) overview of the licenses,

4) how to use Creative Commons-licensed materials, and

5) how and why to Creative Commons license your own work.

We structured the workshops around the assumption that a person has to understand at least a little bit about copyright, and the aws in the current copyright system, in order to comprehend and appreciate the Creative Commons licensing model. The rst half of the workshop is dedicated to laying that foundation, and to explaining what Creative Commons is. We begin with a showing of the video Get Creative, ${ }^{4}$ which uses appealing animation and real world examples to explain why Creative Commons was founded and how it works.

Participants repeatedly mentioned the video as one of their favorite parts of the workshop. We have found that it is a very effective way to communicate the power of Creative Commons and to get the class engaged so that they will listen to the dry, copyright-related parts that come next.

After the video, the presenter explains the key facts about copyright that are integral to the functioning of Creative Commons:

Copyright happens automatically and lasts for the life of the author plus 70 years.

Copyright is a bundle of rights; you can sign them away exclusively or grant nonexclusive licenses that give multiple people permission to use a work.

Most everything is copyrighted, but creators may not want or need all those rights.

This section of the presentation is not intended to be a comprehensive introduction to copyright law. The purpose is to help the class understand why Creative Commons is important and the major ways that Creative Commons licenses differ from regular copyright.

We follow the copyright overview with an examination of the four license elements and a look at all six licenses. We explain what each license permits and doesn t permit, and emphasize that most academic uses are considered noncommercial. We also show examples of the three different kinds of language that make up a Creative Commons deed (Human Readable, Lawyer Readable, and Machine Readable). The aim here is to help get the class comfortable with the icons and terms used to represent aspects of Creative Commons licenses so that when participants encounter Creative Commonslicensed work in the future, they will be able to identify it and use it appropriately.

The second half of the workshop is comprised mainly of a series of live Web demonstrations that show off the rich deposits of Creative Commons-licensed work available on the Web. The presenter walks the participants through searches on Flickr for photos, ccMixter for music, and MIT OpenCourseWare for class materials. At this point, the class gets really excited. We 
suggest potential uses for these resources, but participants have no trouble coming up with their own ideas.

One librarian who works with the Communications Studies department regularly elds questions about whether students can use popular music in their multimedia projects, and he couldn $t$ wait to show them all the music that was available on ccMixter. A professor who likes to include a lot of images in her conference presentations was thrilled to learn about all the photographs that she could use without worrying about copyright when she posts those presentations online. The range and quality of Creative Commonslicensed material is inspiring.

Before opening up the workshop to questions, we always demonstrate how to apply a Creative Commons license to a Web site or photograph. We show them how to choose a license and where to get the code from the Creative Commons Web site. By now the participants have seen what a wonderful resource Creative Commons has provided, and we hope that they will begin using it to license their own work.

\section{Conclusion}

In an era of increased licensing restrictions and tightening budgets, Creative Commons is an excellent resource for faculty, staff, students, and librarians looking for free, reusable content. Creative Commons is a gift to the academic community, and librarians are the ideal people to spread the word.

\section{Notes}

1. U.S. Const. art. I, 8, cl. 7.

2. Creative Commons, About Creative Commons, creativecommons.org/about/ (accessed May 1, 2008).

3. Creative Commons Wiki, Some Rights Reserved: Building a Layer of Reasonable Copyright, retrieved May 1, 2008, from wiki. creativecommons.org/History (accessed May 1, 2008).

4. Get Creative, mirrors.creativecommons. org/getcreative/ (accessed May 1, 2008). n 